\title{
SIVISTYSTÄ VAI TULOSTEHTAILUA?
}

ARTO MUSTAJOKI (2002)

Tuloksena yliopisto.

Yliopistopaino.

Mihin ollaan menossa? Sitä kysellään nyt joka puolella, ei vähiten korkeakoulumaailmassa. Viime vuosina yliopistoissa on ryskynyt, enemmän kuin aikoihin. Arto Mustajoen kirja on katsaus 90-luvun myrskyisiin vuosiin, Helsingin yliopiston näkökulmasta katsottuna, mutta samalla se on myös kertomus idealistisen tutkija-humanisti Mustajoen seikkailuista hallintobyrokratian ihmemaassa. Mustajoki on halunnut ehkä selvittää myös itselleen, mitä noina vuosina tapahtuikaan yliopistolle - ja mitä Mustajoelle.

Professori, dekaani, työryhmien vetäjä ja vararehtori Mustajoki on ollut näkijänä ja tekijänä siellä missä tapahtuu. Hän sai ansaittua huonomman maineen, kun osalle lankesi ns. likaisen työn teko. Mustajoki veti arviointityöryhmää, joka antoi 1993 paljon porua herättäneen raportin Universitas renovata, ja 1998 Mustajoki sai opiskelijoiden vihat niskoilleen, kun hän johti opintojen pitkittymistä pohtinutta työryhmää. Asiat helposti henkilöityvät, ja ihmisillä oli taipumus lukea ra- portteja kuin piru Raamattua, tai muuten vain intoilla kuulopuheiden ja luulemisten varassa. Uudistaja saa väistämättä myös vihollisia.

Mustajoen kirja on diplomaattista nuorallakävelyä kriittisyyden ja oman verstaan kehumisen välillä. Vuodet hallintomiehenä ovat pehmentäneet Mustajoen ymmärtämään hallintoa, mutta moitettakin löytyy. Hänen mukaansa yhdeksän kymmenestä hallinnon kokouksiin osallistuvasta ei tiedä, mitä ollaan päättämässä, eikä vastuuta halua ottaa kukaan. Oman osansa nokittelusta saavat myös tiedekunnat.

Hallinnonuudistus, arviointi, arvioinnin arviointi, uusi rahanjakomalli, tulosohjaus, tulosvastuu... Menossa on korkeakoululaitoksen lähes tuhatvuotisen historian dramaattisin - ja ehkä kohtalokkain - muutosprosessi. Sen rinnalla jokin 70luvun opiskelijaradikalismi oli auvoinen, harmiton idylli.

Alussa oli hallinnonuudistus, ensimmäinen järkytys, kun professorien ikiaikainen nautintaoikeus päätöksenteossa meni ja opiskelijat ja henkilökunta tulivat mukaan hallintoon. Mutta se oli lähinnä kosmeettista, menneeseen unohtuneen lai- toksen päivittämistä todellisuuteen. Paljon syvemmältä yliopistoparatiisin rauhaa kouraisee raha, sen tuomat paineet ja vaatimukset. Yritysmaailmasta lainatut toimintamallit ja arvot tekevät vahvasti tuloaan tiedeyhteisöön. Yliopisto on tahtoen tai tahtomattaan mukana yleisessä mammonan edessä kumartelussa, ja sen ympärillä Arto Mustajokikin kaartelee, mm. hakiessaan uudelleentulkintaa yliopiston myyttiselle autonomialle.

Kirjan lopussa luo Mustajoki silmäyksen tulevaisuuteen. Kovin paksuja pilviä hän ei horisontissa näe. Hän ei vastusta tulosohjausta, mutta pitää huolestuttavana rahoituksen yksipuolista painotusta soveltavaan tutkimukseen. Slavistiikan professori pelkää tutkimuksen laadun kärsivän määrän kustannuksella ja opiskelijamassojen paineen johtavan korkeimman koulutuksen opinahjon muuttumiseen keskiasteen kouluksi, yliopiston "lukioistumiseen". Monenlaisia tavoitteita ja tarpeita on kirjattu, mutta yhtä termiä jäi kaipaamaan: "sivistystä”.

Pekka Matilainen 